奨油の好みと地域特性

高木 亨

(立正大学)

\title{
Regional characteristics and palatabilitiy of soy sauce in Japan
}

\author{
Akira Takagi \\ Rissho University, 1700, Magechi, Kumagaya-shi, Saitama, 360-0194 \\ 干360-0194 埼玉県熊谷市万吉 1700
}

The regional characteristics and palatability of soy sauce in Japan are discussed in this paper. The questionnaire survey was carried out to investigate the palatability of soy sauce in Japan. It was conducted at 37 high schools and one junior high school in 24 prefectures in 1998. The investigation involved 1,740 parents of these school students.

The questionnaire survey clarified that the regional difference was based on the strength of personal interest in soy sauce and the type of soy sauce, use method, supplier and the market share.

The market share of five major soy sauce manufacturers in Japan could distinguish all regions of Japan into two classes using the percentage score of the share.

The five major soy sauce manufacturers ( 5 -MSM) were Kikkoman Corp. in Noda-shi, Yamasa Corp. and Higeta Shoyu Co., Ltd., in Choshi-shi, which were all in the Chiba Prefecture, Marukin Chuyu Co., Ltd., in Shodo Island in the Kagawa Prefecture, and Higashimaru Shoyu Co., Ltd., in Tatuno-shi in the Hyogo Prefecture.

The percentage of less than $50 \%$ of the market share was defined as the A-block. On the other hand, the percentage of greater $50 \%$ of the market of $5-\mathrm{MSM}$ was defined as the B-block.

The five regions of Kyushu, Sanyo, Sanin, Hokuriku, and Tohoku belonged to the A -block. The A-block has the common characteristics as follows: 1 ) Consumer was very interested in soy sauce. 2 ) Several types of soy sauce were distinguished for use in various cooking. 3 ) Customers often purchased soy sauce directory at their favourite soy sauce manufacturer. 4) The consumption of Koikuchi-shoyu (deep color soy sauce) occupied a low proportion. The above data concluded that the intimate relationship between the local area soy sauce manufacturers and consumers was high in these A-block regions.

The six regions of Hokkaido, Kanto-Koushin, Tokai, Kansai, Shikoku, and Okinawa belonged to the B-block. The B-block had some opposite characteristics versus the A-block as follows: 1 ) Consumer was slightly interested in soy sauce. 2 ) The same type of soy sauce was used for various cooking. 3 ) Soy sauce was mainly purchased at the supermarket. 4 ) The top market share of soy sauce was formed by 5 -MSM.

As a result, it was shown that the preference of "taste" differed regionally over all of Japan. The regional difference of palatability could regionally help the small and medium soy sauce manufacturers in Japan. 


\section{I 緒 言}

本研究は, 諲油醸造業の存立形態に関する研究1) 6)の 一環として, 消費者の槒油の好及と槒油の消費動向につ いて，その地域的特性を明らかにするものである。

地域には独特の食文化があり，それらを形成するもの の一つに調味料があげられる。この代表的なものに味噌 と醤油があげられる。味噌は「手前味噌」と評されるほ ぞ, 地域の及ならず家庭による違いまでが明瞭にあらわ れており，食文化の形成に大きな影響を与えているとい える。同じくわが国を代表する発醳調味料である䙵油は, 広く一般的に用いられているが, 味噌ほどその地域的差 異に注目されてこなかった。味噌と異なり家庭ではほと んど作られることがなくなった醤油は, キッコーマン陎， ヤマサ酱油侏, ヒゲタ酱油侏, マルキン忠勇物, ヒガシ マル奨油侏の大手 5 社による葟占が進んでいるようにみ える。2001年の大手 5 社の出荷量は $507,460 \mathrm{k} l$, 中小酱 油醸造業者の合計は $519,893 \mathrm{k} l$ となっており, 大手 5 社 のシェアは $49.4 \%$ となっている（日本酱油協会資料）。

しかし, 酱油を生産している醸造業者は2001年現在でも 全国に1,599あり，そのほとんぞが中小醸造業者である7。 これらの醸造業者は地域に根ざし, その地域の味のもと となる奨油を生産している。こうした醸造業者を存立さ せているものの一つに消費者の好及があると考えた。

食文化の地域的な差異に関する研究は, 石川らによる 研究がある8 $\left.{ }^{8)}, 9\right)$ 。石川らは地域の違い, すなわち地域性
に着目し，食文化への理解を深め上うと試みた。主食や 豆, 野菜, 魚, 肉, 味付けなど様々なものに着目し, 分 布図を用いて地域による食文化の差異を明らかにしてい る。これは, 従来の食文化研究に多くみられた特定の地 域の特色ある食生活や食文化に注目するという視点とは 異なる視座を示した。石川らの研究が第三者による聞き 取り調査を基にした資料を用いて，複数の食品を取り上 げ分析しているのに対し，本論は，上り直接的に消費者 の酱油の好みをとらえることで, 地域的な特徽の明確化 を試みた。な㧍, 奨油の種類に関する表記は, 日本農林 規格ではすべて平仮名による表記になっているが，本論 では意味が明確にわかる漢字表記とした。

\section{II 調査方法}

本研究の中心となるアンケート調査は, 主として立正 大学の卒業生が勤務する高等学校 37 校と中学校 1 校にお いて, 各校50部（1 クラス分）を目安に配布し, 生徒の 保護者に回答してもらう方法をとった。その範囲は北海 道から沖縄までの 24 道府県となっている（図 1 )。これ ら回答が得られた地域をもとに, 回答総数などを考慮し て便宜的に13地域に区分した。以下，この地域区分によ り分析を進める。調查票には, 奨油の購入価格・購入先, 消費量といった設問のほか, 奨油への関心についてや料 理時の奨油の使い分けなどの問いを設けた（表 1 )。配 布から回収をでの期間は1999年 7 月下旬から 9 月上旬の 約 2 ヶ月間で, 回収数は 1,740 , 回答者の内訳は男性 105 ,

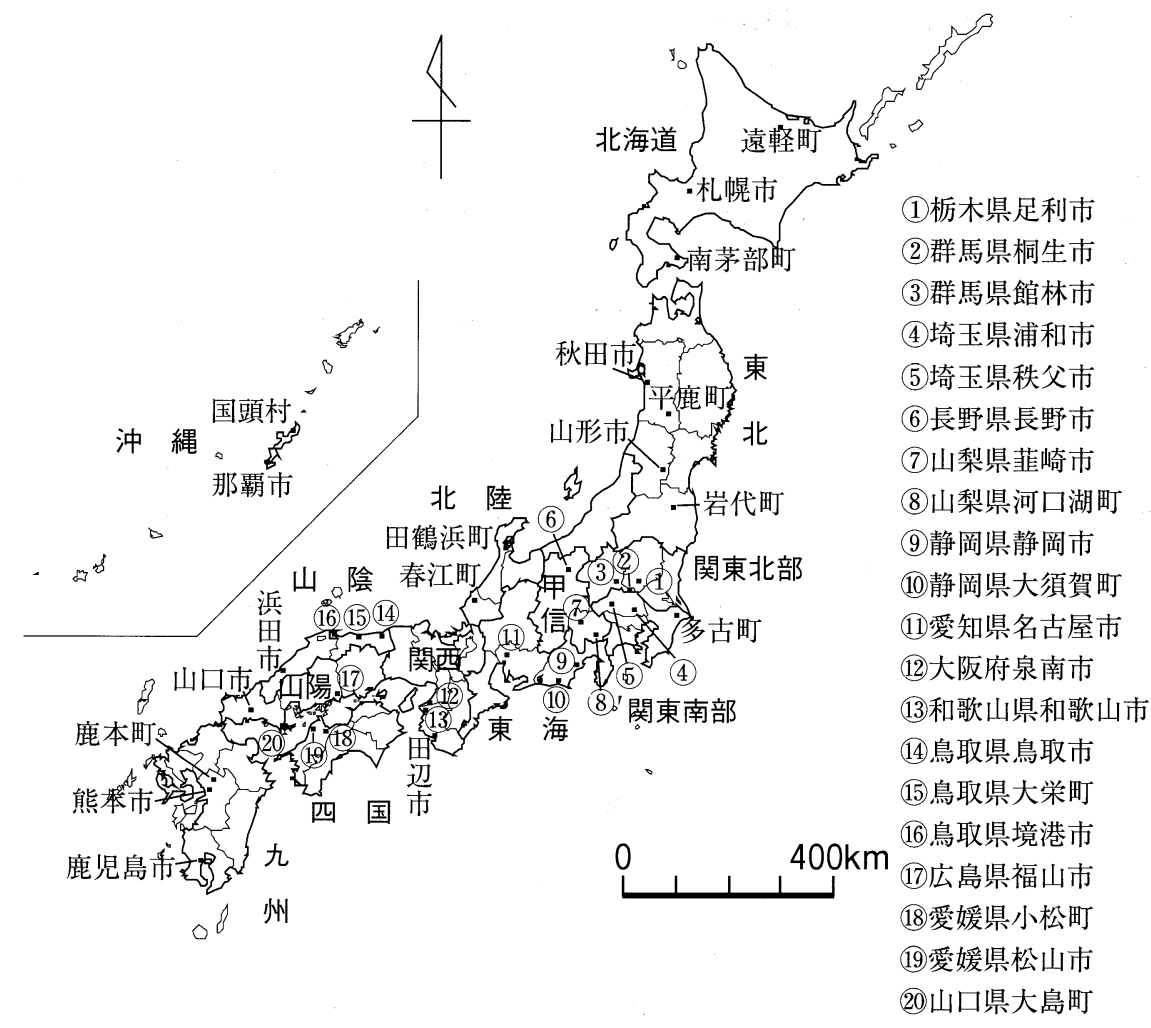

図 1 アンケート実施校の所在地と地域区分 ※市町村名はアンケート実施当時のもの 


\begin{tabular}{|c|c|}
\hline 設＼cjkstart問 & (こちらにご記入ください) \\
\hline $\begin{array}{l}\text { (1)-1：しょうゆに対して「こだわり」を抢もちですか〈該当 } \\
\text { するものに○をつけてください〉 }\end{array}$ & $\begin{array}{ll}\text { 1. もっている } & \rightarrow \text { 設問(1)- } 2 へ \\
\text { 2. もっていない } & \rightarrow \text { 設問(2)へ }\end{array}$ \\
\hline $\begin{array}{l}\text { (1)-2: どのようなところに，「こだわり」をもっていますか } \\
\text { 〈右の欄の該当するものに○をつけてください〉 }\end{array}$ & $\begin{array}{l}\text { 1. 銘 柄 } \quad 2 \text {. 高級しょうゆ } \\
\text { 3. 丸大豆 } \\
\text { 5. その有機栽培原料 } \\
\end{array}$ \\
\hline $\begin{array}{l}\text { (2)- } 1 \text { ：普段お使いのしょうゆのメーカー名を抢教えください } \\
\text { (例 : キッコーマン・ヤマサ・マルキンなど) }\end{array}$ & メーカー名 : \\
\hline $\begin{array}{c}\text { (2)- } 2 \text { : 普段お使いのしょうゆの種類を右の欄からお選びくだ } \\
\text { さい（しょうゆのラベルに記入してあります） } \\
\text { 〈該当するものに○をつけてください〉 }\end{array}$ & 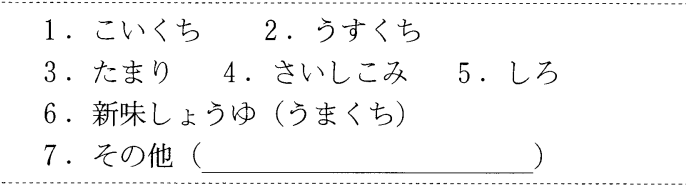 \\
\hline (2)-3 : 価格をお教えください（1 掞ペットボトル） & 1 恍ペットボトル_—円 \\
\hline (3)：一月当たりのしょうゆの消費量をお教えください。 & 一月当たり約__咣 \\
\hline $\begin{array}{l}\text { (4)-1 : 刺身などの「つけしょうゆ」·おひたし・冷や奴などの } \\
\text { 「かけしょうゆ」·煮物などの「料理しょうゆ」のようにしょう } \\
\text { ゆの使い分けをされていますか }\end{array}$ & $\begin{array}{cc}\text { 〈該当するものに○をつけてください〉 } \\
1 . \text { している } \rightarrow \text { 設問(4)- } 2 へ \\
2 . し て い な い ~ & \rightarrow \text { 設問(5)へ }\end{array}$ \\
\hline $\begin{array}{l}\text { (4)- } 2 \text { : どのような使い分けをしていますか. 右の欄へ, 具体 } \\
\text { 的にご記入ください. }\end{array}$ & 使用法： \\
\hline $\begin{array}{l}\text { (5)- } 1 \text { :「めんつゆ」はお使いですか } \\
\text { 〈右の欄の該当するものに○をつけてください〉 }\end{array}$ & $\begin{array}{l}1 . \text { 使っている } \rightarrow \text { 設問(5)- } 2 \cdot 3 \cdot 4 へ \\
2 . \text { 使っていない } \rightarrow \text { 設問(6へ }\end{array}$ \\
\hline (5)-2：「めんつゆ」はいつ頃からお使いですか & 年前ごろから \\
\hline (5)- 3 :「めんつゆ」のメーカーを教えてください & メーカー名 : \\
\hline (5)- 4 :「めんつゆ」を使った理由とその用途を教えてください & $\begin{array}{l}\text { 理由: } \\
\text { 用途 : } \\
\end{array}$ \\
\hline $\begin{array}{l}\text { (6) : しょうゆの主な購入先をお教えください. } \\
\text { (6)- } 1 \text { : お店で購入の場合. } \\
\text { お店の種類を右の中からお選びください. } \rightarrow \\
\text { 店名と所在地をご記入ください. }\end{array}$ & 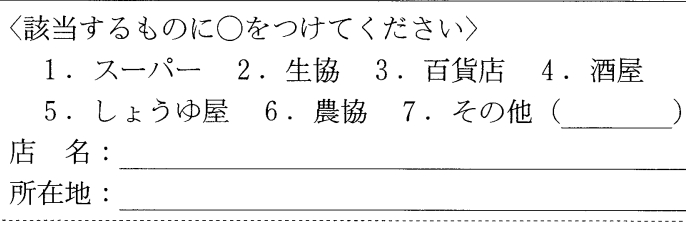 \\
\hline $\begin{array}{l}\text { (6)- } 2 \text { : 通信販売で購入の場合, 購入先と住所をご記入くださ } \\
\text { W }\end{array}$ & $\begin{array}{l}\text { 購入先名 : } \\
\text { 所 在 地 : }\end{array}$ \\
\hline $\begin{array}{l}\text { (6)- } 3 \text { : その他の購入方法（自家製など）がありましたらご記 } \\
\text { 入ください }\end{array}$ & その他： \\
\hline
\end{tabular}

女性 1,635 であった。回答者の平均年齢は 41.0 歳, 平均 世帯人数は 4.8 人である。

\section{III 結果及び考察}

\section{1 ．酱油の家庭での消費量}

表 2 に1999年における $1 l \mathrm{PET}$ ボトル入り奨油の平均 購入価格と 1 世帯での 1 ヶ月当たりの平均酱油消費量を 示した。価格は全国平均では354円となるが，東北の444 円から四国の292円までと幅がある。この金額は1999年 の小売物価統計調査による平均価格302円より50円ほぼ 高くなっている。

1 世帯 1 ヶ月当たりの奨油消費量は, 平均 $1.2 l$ であ り，奨油生産量を全世帯数で割った 1 世帯当たりのひと
月の消費量 $1.8 l$ より低い結果となっている。奨油生産 量には一般消費者向けの奨油のほか, 業務用や加工原料 用の奨油が含まれているため，このような結果になった と思われる。罗油生産量が最も多かった時代の 1 世帯当 たりひと月の平均消費量は $3.3 l$ （1970年）であり，大幅 に消費量が減少していることがわかる。

また，消費量の地域差はわずかであるが，東北，関東 北部, 関東南部, 北陸では $1.4 l$ となっており東日本で 高く西日本で低い傾向がみられた。

\section{2. 酱油への消費者の「こだわり」}

1）奨油の何に「こだわり」を持っているのか 日常の料理に欠かせない滰油であるからこそ，消費者が 「こだわり」を持って使うことが奨油への意識の高さや 
表 2 洒油購入価格と1世帯ひと月当たり の消費量 (1999年)

\begin{tabular}{lr|cc}
\hline & & $\begin{array}{c}1 l \text { PET 平均 } \\
\text { 価格(円) }\end{array}$ & $\begin{array}{c}\text { 月当たり } \\
\text { 消費量 }(l)\end{array}$ \\
\hline 全 & 国 & 354.9 & 1.2 \\
\hdashline 北海 道 & 353.3 & 1.2 \\
東 & 北 & 444.3 & 1.4 \\
関東北部 & 321.3 & 1.4 \\
関東南部 & 321.3 & 1.4 \\
甲 & 信 & 268.3 & 1.2 \\
東 & 海 & 322.0 & 1.1 \\
北 & 陸 & 392.5 & 1.4 \\
関 & 西 & 362.7 & 1.0 \\
山 & 陰 & 397.0 & 1.2 \\
山 & 陽 & 404.7 & 1.1 \\
四 & 国 & 292.0 & 1.1 \\
九 & 州 & 365.3 & 1.1 \\
沖 & 縄 & 369.5 & 0.8 \\
\hline
\end{tabular}

商品選択の際の指標になると考えた。「こだわり」とは 消費者が酱油を購入や使用するときに，もっとも重要視 するものとする。図 2 はアンケートを実施した学校別に 「こだわり」の有無について得た回答を示したものであ る。全体的な傾向としては, 東北, 関西, 山陽, 九州で 「こだわりを持っている」割合が比較的高く, 関東では 「こだわりを持っていない」割合が高くなっている。

詳細にみると, 札幌市・秋田市・山形市, 和歌山市,
浜田市, 福山市・大島町・山口市, 鹿児島市で「こだわ りを持っている」割合が高くなっている。一方, 南茅部 町, 福島市, 関東南部の多古町や浦和市（当時）と秩父 市，それから長野市，大須賀町，大栄町などでは「こだ わりを持っていない」割合が高い。これらのアンケート 先の回答をその所在地を含む地域の代表的な回答と考元， それをもとに地域別にまとめたものが図 3 である。全国 的にみると「こだわりを持っていない」が52\%とわずか に過半数を超えるが，「持っている」と「持っていない」 はほぼ半数ずつになっている。しかし, 地域ごとにみて いくと, 図 2 から読及取れた傾向がより鮮明になってい る。すなわち「こだわりを持っている」との回答が東北 で53\%, 関西 $(55 \%)$, 山陽 (64\%), 九州 $(57 \%)$ の各 地域で過半数を占めている。また，「こだわりを持って いない」との回答は, 関東北部 $(58 \%)$, 関東南部 (70 $\%)$, 甲信 (64\%), 東海 (56\%) で，半数を大きく超え ていることが読反取れる。すなわち，「こだわりを持っ ている」地方は東北地方と関西 ·山陽・九州であり, 「こだわりを持っていない」地域は, 北海道, 関東, 甲 信, 東海, 北陸と山陰, 四国, 沖縄とに大別できる。

次に「酱油の何にこだわりを持っている」か加対する 回答についてみると（図 4), 多くの地域で関心が高か ったのが「銘柄（酱油醸造業者）」である。次いで原料 の「丸大豆」を使用した製品,「有機栽培原料」を使用 した製品へのこだわりが強くあらわれている。そして 「塩分」を考えて減塩奨油を用いているなどの回答がみ

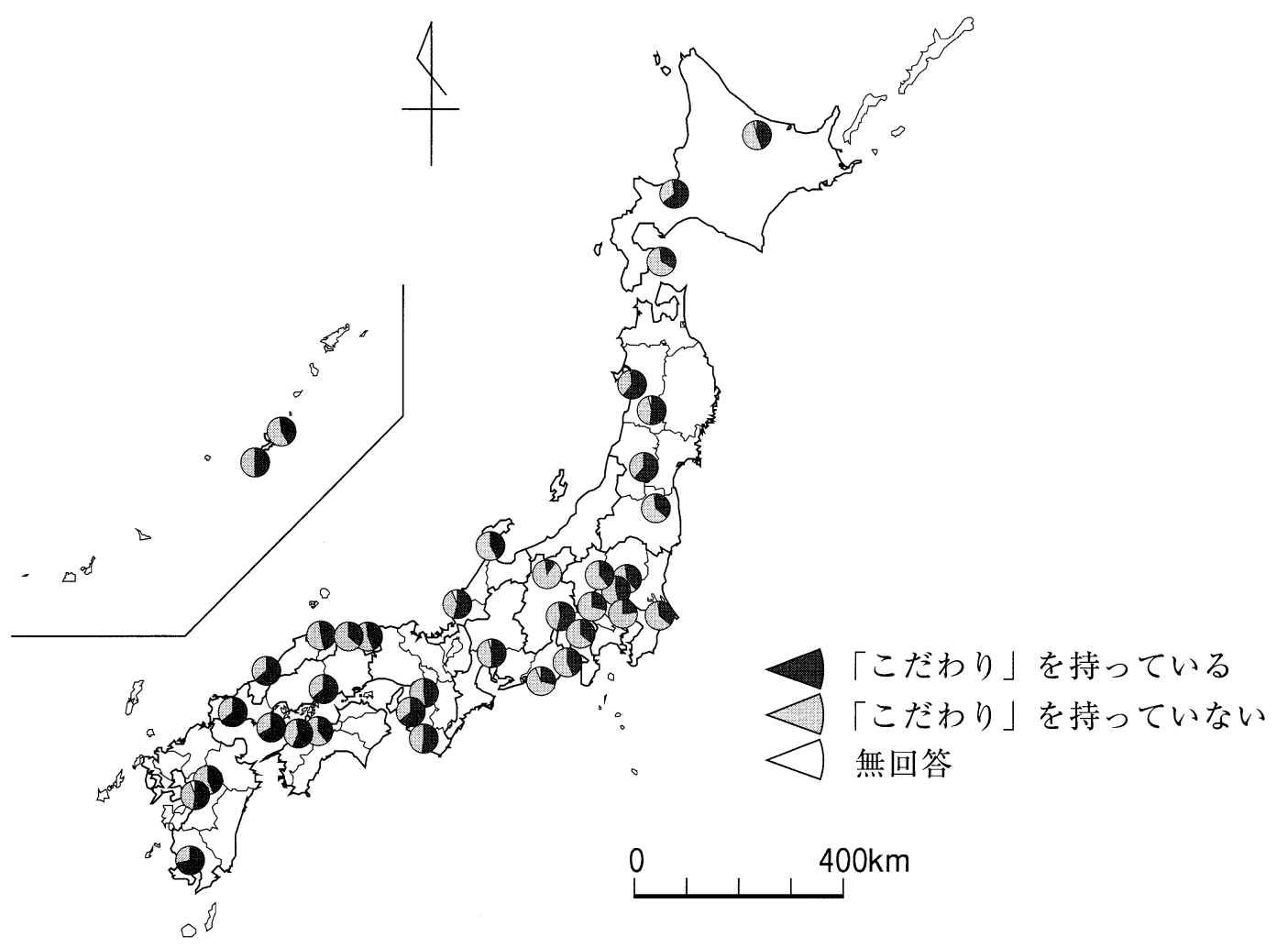

図 2 噂油の「こだわり」について

※アンケートのとりまとめを依頼した学校の所在地別に示してある。 
奨油の好みと地域特性

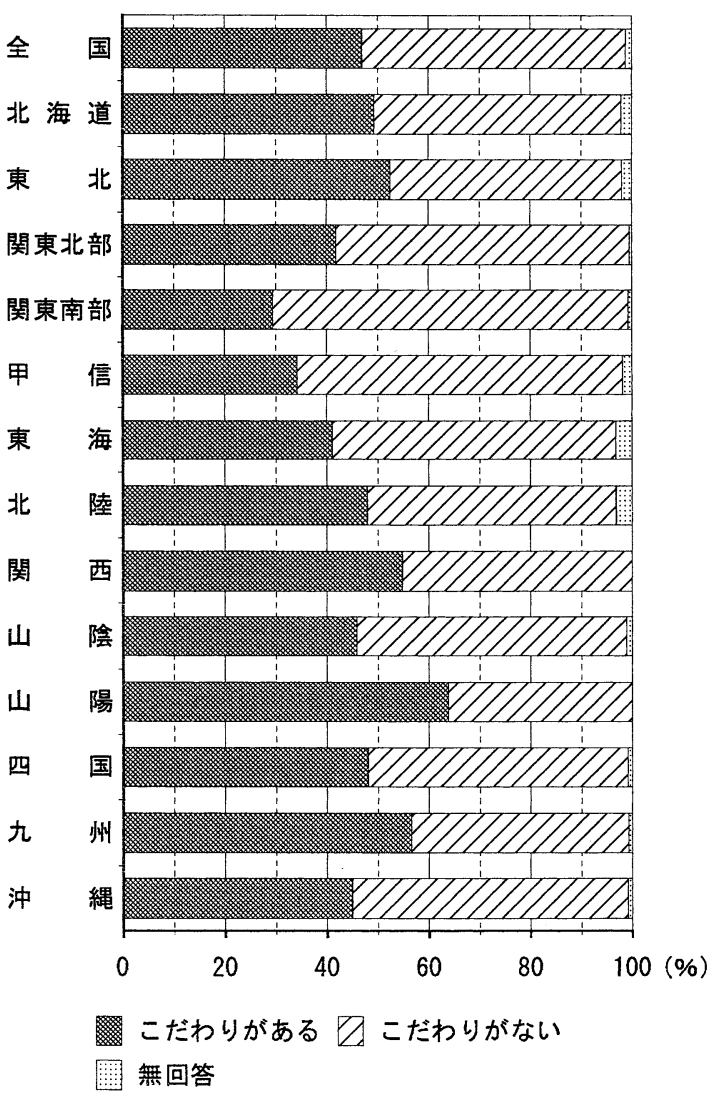

図 3 地域別にみた奨油に対する「こだわり」

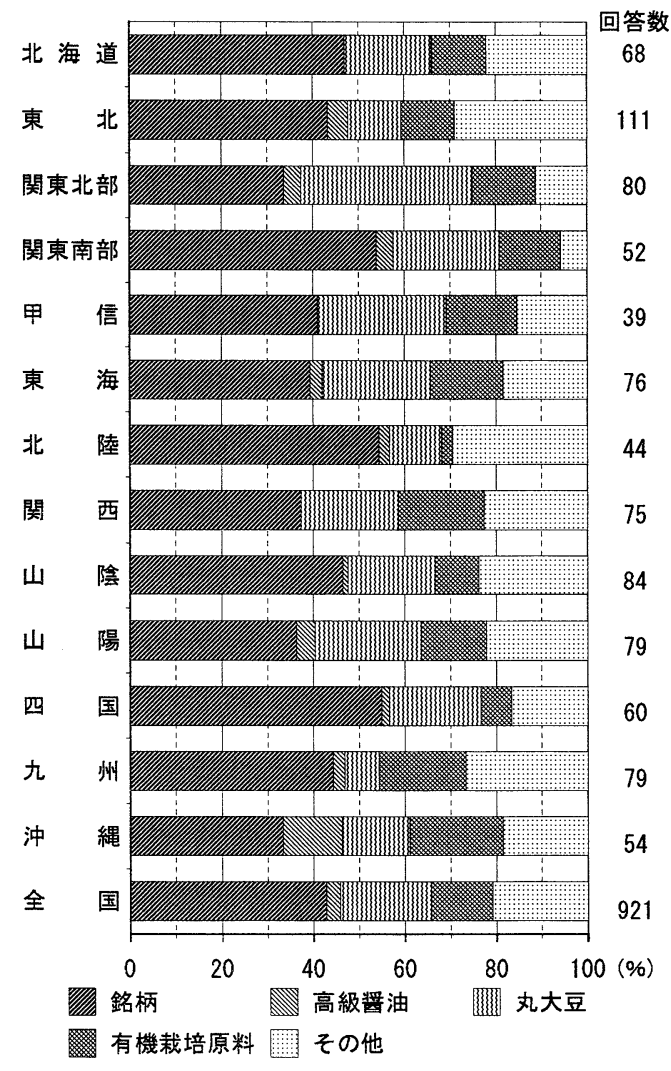

図 4 酱油への「こだわり」の内容
られた。その一方で「高級奨油」への関心は低くかった。 これらの結果は, 購入する際の判断材料として, 価格を 重視するのではなく，使い慣れた銘柄や，安全な原料な どを重視しているとみることができる。こうした「こだ わり」の傾向は地域的には大きな差異はみられず，全国 的にはほぼ同じ傾向にあるといえる。
2) 銘柄への「こだわり」 本項では「こだわり」 のうち, 関心が高かった銘柄（奨油醸造業者）について 検討する。銘柄に注目することで, 奨油の流通範囲と消 費の動向を明らかにする。図 5 は各地域ごとに使用され ている銘柄の割合を示したものである。全国的には，奨 油業界のトップブランドであるキッコーマンが $44 \%$ を占

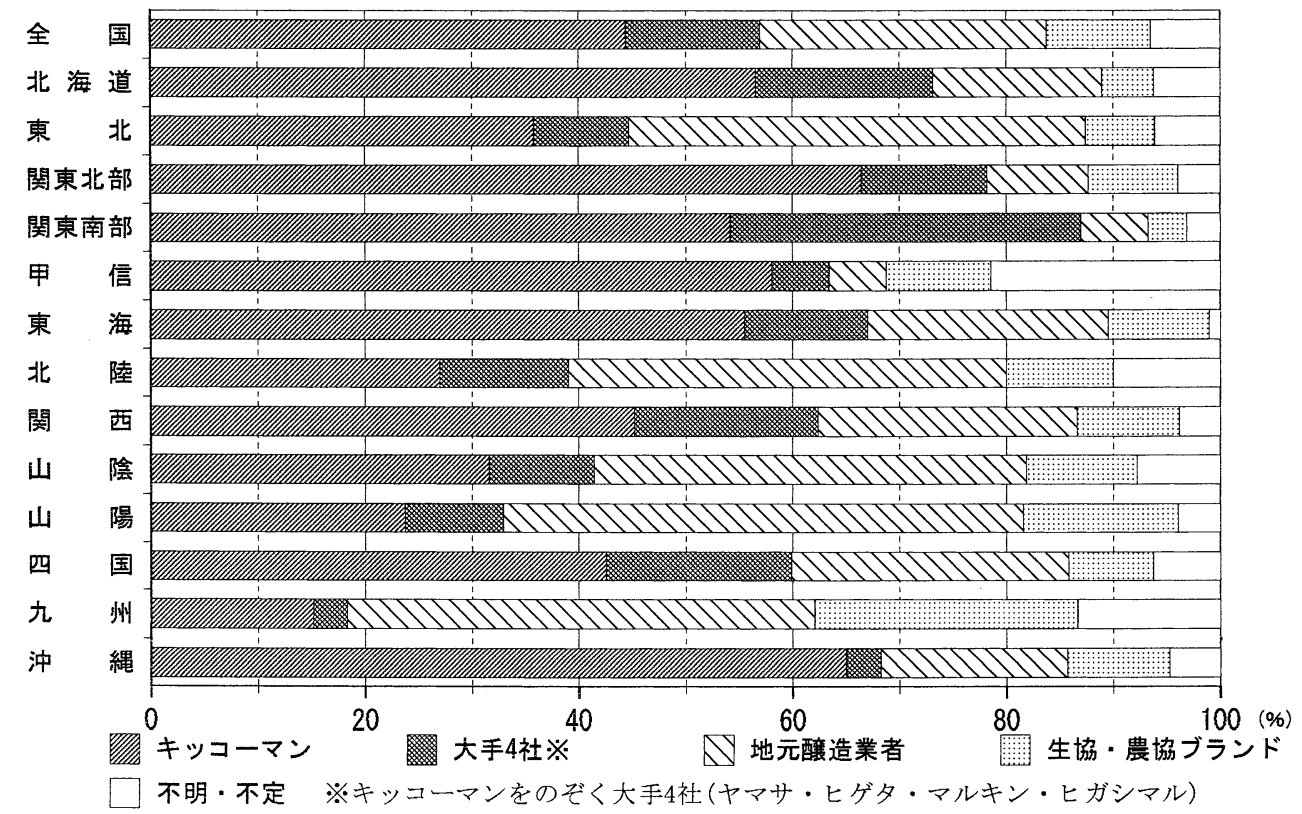

図 5 酱油の銘柄（奨油醸造業者）別使用割合 
日本食生活学会誌 Vol.15 No.4（2005）

表 3 主に使用する奨油の銘柄(酱油醸造業者)数とその所在地

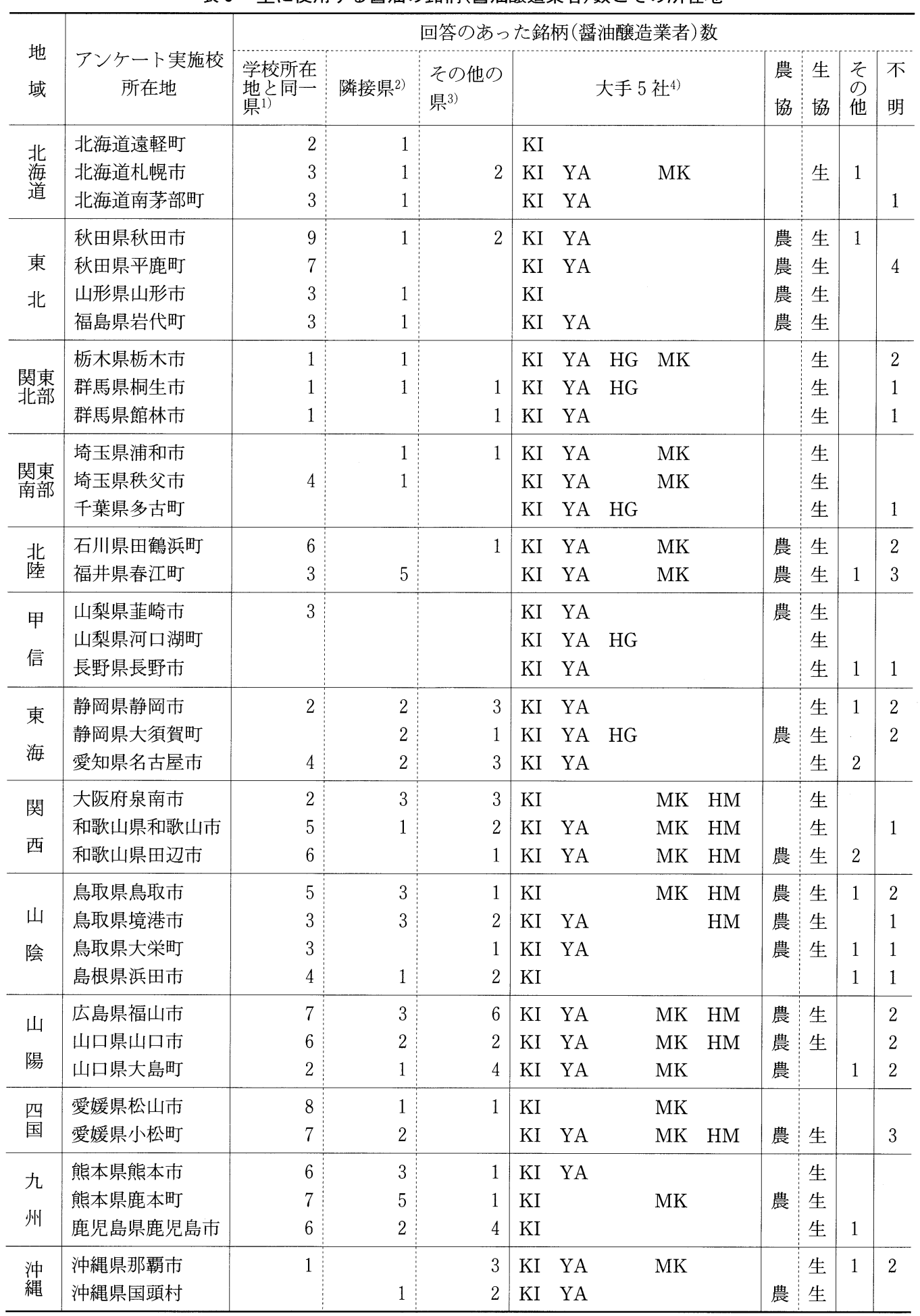

注:

1) 学校所在地と同一県内に立地する銘柄の数 (大手 5 社を除く)

2) 学校の所在県に隣接する県に立地する銘柄の数 (大手 5 社を除く)

3）上記以外の都道府県に立地する大手 5 社以外の銘柄の数

4） $\mathrm{KI}$ : キッコーマン, YA : ヤマサ, HG : ヒゲタ, MK : マルキン, HM : ヒガシマル

※ 市町村名はアンケート実施当時のもの. 


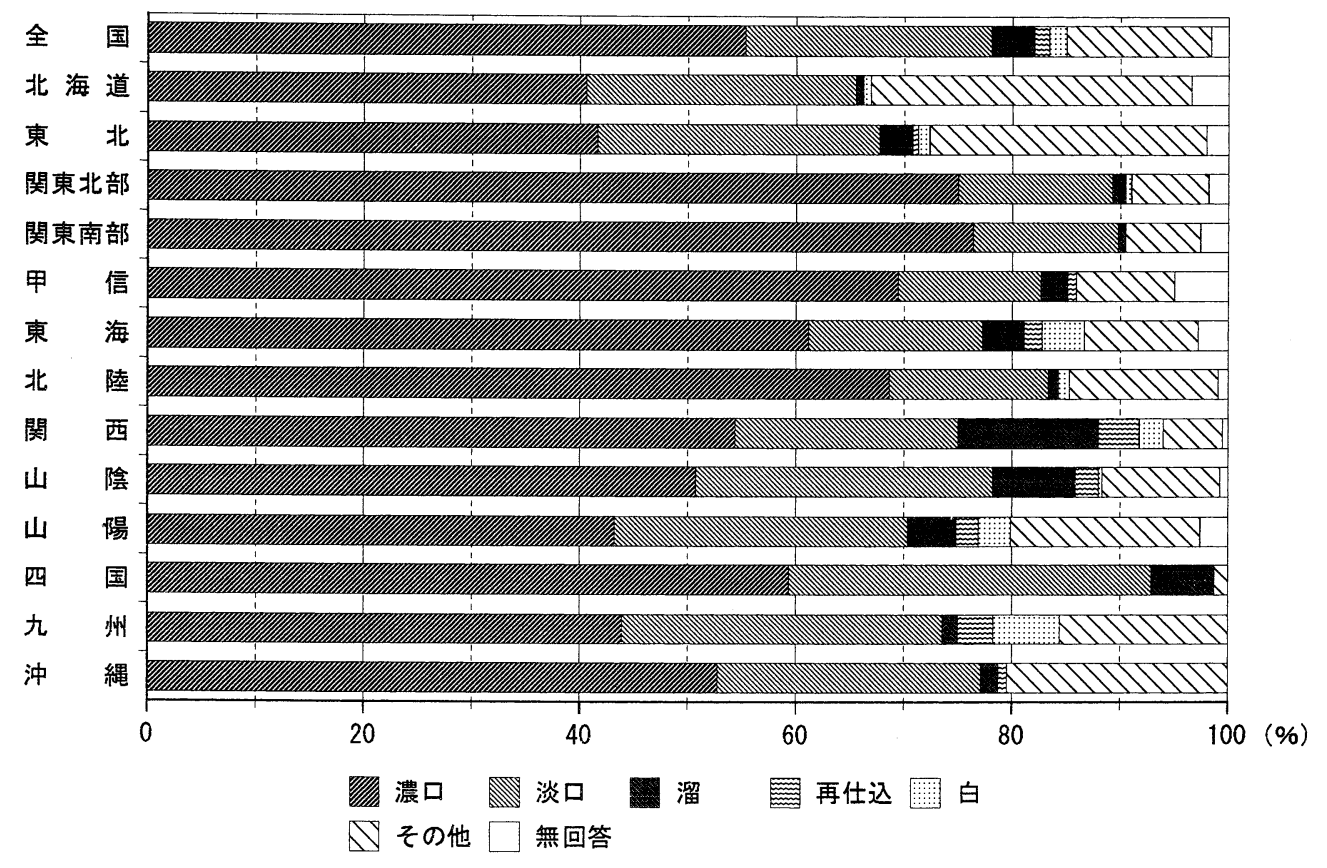

図 6 酱油の種類別使用割合

め, その他の大手 4 社（ヤマサ・ヒゲタ・マルキン・ヒ ガシマル）が $13 \%$, 生協·農協をのぞく中小の地元醸造 業者が $27 \%$, 生協・農協ブランドが $10 \%$ という構成にな っており，大手 5 社で $57 \%$ を占めている。

キッコーマンの割合が50\%を超えるのは, 北海道（57 $\%)$, 関東北部 $(67 \%)$, 関東南部 $(54 \%)$, 甲信 $(58 \%)$, 東海 (56\%) と沖縄（65\%）の各地域である。次いで40 \%台が, 関西 $(45 \%) \cdot$ 四国 $(43 \%)$ となっている。こ れらの地域にはキッコーマンの工場が立地していたり10), また支店や代理店を通じた販売網11)があるなど, 流通面 で有利な条件があることがあげられる。

キッコーマン以外の大手 4 社の割合をみると, 北海道 $(17 \%)$, 関東南部 $(33 \%)$, 関西 $(17 \%)$, 四国 $(17 \%)$ で高い。さらにキッコーマンを含めた大手 5 社の割合は, 北海道と関東では70\%を超えている。甲信, 東海, 関西, 四国, 沖縄でも $60 \%$ 超となっている。とくに関東南部で は87\%を占め, 大手 5 社による独占市場ともいえる。

その一方で, 東北, 北陸, 山陰 - 山陽, 九州の各地域 では, 大手 5 社以外の地元醸造業者の割合が高くなって いる。その割合は，東北で $43 \%$, 北陸 $41 \%$, 山陰 $40 \%$, 山陽 $49 \%$, 九州 $44 \%$ であり, 地元醸造業者の奨油が主に 使われていることがわかる。さらに，整理すると（表 3 ), これらの地域では, 同一県内もしくは隣接県の銘柄が数 多くみられる。さらに, 同じ地域において多数の銘柄が 用いられていることが読み取れる。これは, 消費者が地 元または近接地域の奨油を好んでおり, 加えて消費者の 好みに応じた奨油が複数存在していることを示している。 地域ごとにみると，東北では同一県内の銘柄が数多く みられる。また, 沖縄をのでく関西以西では同一県内の ほか，隣接県またはその他の県の銘柄も多くみられる。
これは酱油の流通が広範囲にわたっていることを示して いる。その一方, 関東では大手以外の銘柄数は少なく, 大手製品が多く消費されているといえる。

大手 5 社では, キッコーマンとヤマサが全国各地で, マルキンが比較的広範囲で用いられている。一方, ヒゲ タは関東·東海で, ヒガシマルが関西以西に特化してい る。また, 農協ブランドは北海道と関東をのぞく地域, 生協ブランドはほぼ全国的に用いられている。

3. 主に使われている酱油の種類と酱油の使い分け

1) 酱油の種類 まず全国的な動向を概観する (図 6 )。2001年の酱油生産量のうち83\%を濃口（こいく ち）奨油が占めている12)が，アンケート調査結果では全 国平均で55\%であった。次いで淡口（うすくち）奨油が $23 \%$ ，その他 $13 \%$ となっている。次に，奨油の種類によ る地域的な特徵をみると, 濃口䛜油は関東 ·甲信・東 海·北陸で $60 \%$ 超を占めているが，北海道·東北・山 陽·九州では50\%を切っている。関西・山陰·沖縄では 50\%をわずかに超える程度である。淡口奨油は北海道 · 東北と関西以西で20\%を超え，四国では34\%を占めてい る。関東・甲信・東海・北陸では13～16\%である。溜 （たまり）奨油は関西 $(13 \%) \cdot$ 山陰 $(8 \%) \cdot$ 山陽（ 5 $\%$ ）四国（6\%）となっており関西から中国・四国に かけて比較的高くなっている。また，東北でも $3 \%$ を占 めている。溜奨油の本場といえる東海では $4 \%$ であった。 再仕込奨油は, 関西で $4 \%$, 山陰 ·山陽が $2 \%$, 九州が $3 \%$ である。白奨油は主産地である東海で $4 \%$ を占める ほか, 九州で $6 \%$, 関西で $2 \%$, 山陽で $3 \%$ となってい る。

一方，その他の奨油の割合が高かったのが，北海道・ 東北・山陽·九州·沖縄である。これらの地域では $15 \%$ 
を超えている。東海・北陸・山陰でも10\%を超えている。 その他の眢油とは, 従来の濃口奨油を基本に, 昆布だし などのうまみ成分を添加した酱油である。一般に「うま くち」「昆布奨油」や「新味奨油」「だし奨油」などと呼 ばれている。上記のような地域で，例えばアミノ酸など の，うまみ成分を強調した奨油を比較的多く用いている

\section{ことがわかる。}

従来, 濃口酱油は関東, 淡口奨油は関西で特化してい るといわれてきたが13)，そのように単純ではなく，地域 に応じていくつかの種類が用いられていることがわかる。

また，醤油加工品である「めんつゆ」は，全国でみる と $82 \%$ の家庭で使用されていた。使用割合の地域的な差 異は小さく, 最も高い九州で $91 \%$, 低い北陸・関西でも 69〜70\%であった。このことから「めんつゆ」は，多く の家庭で欠かせない調味料の一つになっているといえる。 「めんつゆ」を使用する理由として，使ってみたら「簡 単」で，しかも「おいしい」ことをあげている。「めん つゆ」の簡便さと味の良さが多くの家庭で受け入れられ たものと思われる。「めんつゆ」を使いはじめた時期は, 平均すると13年前であった。1980年代はじめに登場した 「めんつゆ」が，1980年代後半から90年代はじめにかけ て急速に普及していったことと一致している14)。

2 ）醤油の使い分け奨油の使い分けとは，料理 に応じて異なる奨油を使い分けることを意味している。 例えば，「煮物には淡口奨油を使用し，冷や奴には濃口 奨油を用いる」ことなどが，奨油の使い分けをしている

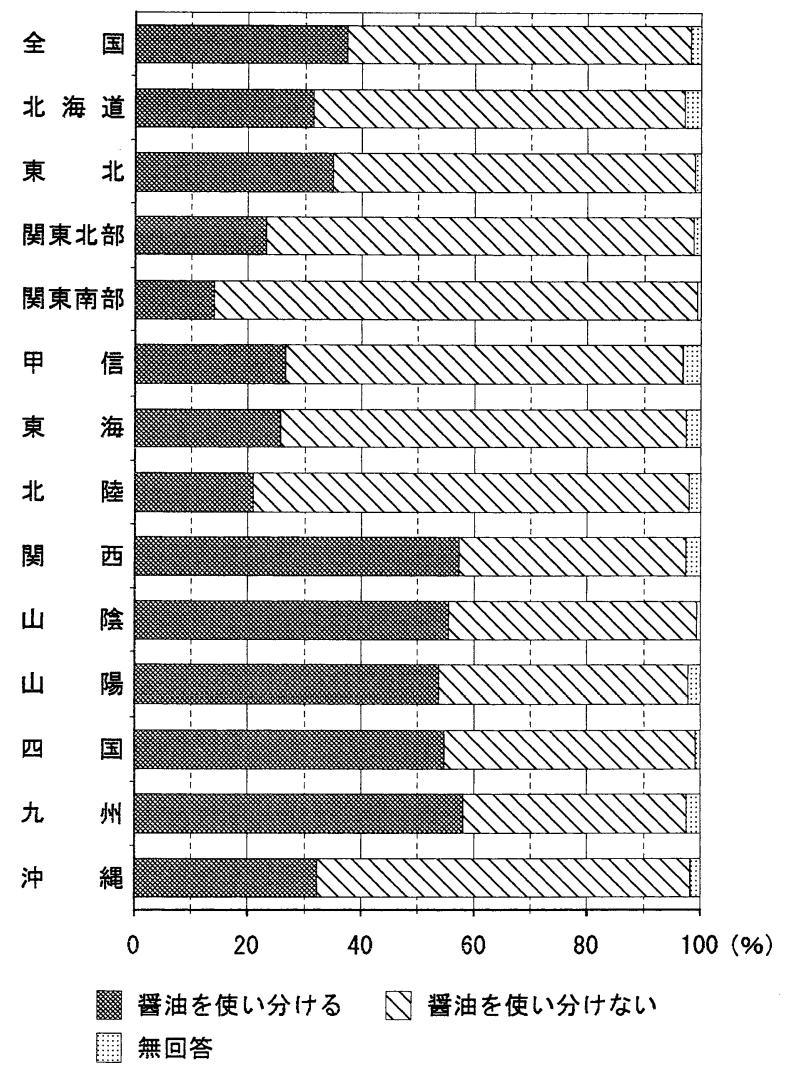

図 7 地域別にみた郒油の使い分けについて
ことになる。逆にすべての料理に使う奨油が一種類のみ の場合は，奨油の使い分けをしていないことになる。使 い分けの有無は, 奨油を使う際の消費者の意識と「味」 へのこだわり,さらには「味」の風土性をみることがで きる。

醤油の使い分けの有無を表したのが図 7 である。沖縄 をのぞく関西以西で54～58\%と50\%を超えて奨油の使い 分けをしている。一方, 関東南部では85\%, 北陸で $77 \%$, 関東北部で76\%，東海 $72 \%$ ，甲信70\%と使い分けをして いない割合が高くなっている。北海道では使い分けをし ている割合が $31 \%$ で，東北（35\%)，沖縄（32\%）とと もに両者の中間的な位置づけとなっている。全国では 37 \%が料理に応じて奨油を使い分けており，61\%が使い分 けをしていないという結果となった。関西から九州にか けての地域では使い分けをしている割合が高く, 関東か ら東海にかけての地域では低くなっていることが読み取 れる。

具体的な使い分けの事例を北から南に示すと表 4 のよ うになる。使い分けの内容は, 使い分けの特徵がわかり やすいものを回答のなかから抽出したために, 実際の回 答数とは一致しない。

使い分けの方法としては，啰油の味の違いで使い分け たり，種類や銘柄，価格などで使い分けたりしている。 また，刺身には刺身専用の奨油を用いる例が多いようで ある。地域によっては淡口奨油をかけ眢油として用いて いるところもある。各地で料理に応じた奨油の使い分け がおこなわれていることが表から読み取れる。

使い分けをおこなう地域とそうでない地域があること については，「上方の食い倒れ，坂東の着倒れ」の伝統 が続いている15) とか, 歴史的・文化的な背景の違いによ る16)などがその要因ではないかといわれている。奨油の 使い分けは地域の産物や伝統的な食の習慣に大きく影響 していると考えられる。

\section{4. 酱油の購入先}

図 8 は，奨油を主にどこから購入しているかを示した ものである。各地域ともスーパーマーケットで滰油を購 入する家庭が最も多く，40～70\%である。中でも $60 \%$ を 超えるのは東北 $(61 \%)$, 関東北部 $(61 \%)$, 関東南部 $(70 \%)$, 東海 $(70 \%)$, 沖縄 $(61 \%)$ となっている。次 いで多いのが生活協同組合（以下，生協）からの購入で, 北海道 $(30 \%)$ ，九州 $(21 \%)$ などで高くなっている。 一方, 農協からの購入は, 割合が高くても北陸 $(11 \%)$, 四国・沖縄（ともに $9 \%$ ）であり，生協より低い割合と なっている。

奨油醸造業者から直接購入する家庭は, 北陸以西で多 くみられる。とくに北陸では $22 \%$ 家庭が滰油業者から 直接購入している。この他関西から九州にかけての地域 で10～15\%を占めている。また，東北（７\%）, 関東南 部（４\%）などでもわずかではあるが, 奨油業者から直 接購入している家庭がみられた。 
表 4 諲油の使い分けの事例

\begin{tabular}{|c|c|c|}
\hline 地域 & 府県名 & 使い分けの内容 \\
\hline $\begin{array}{l}\text { 北 } \\
\text { 海 } \\
\text { 道 }\end{array}$ & $\begin{array}{l}\text { 北海道 } \\
\text { 北海道 } \\
\text { 北海道 } \\
\text { 北海道 }\end{array}$ & 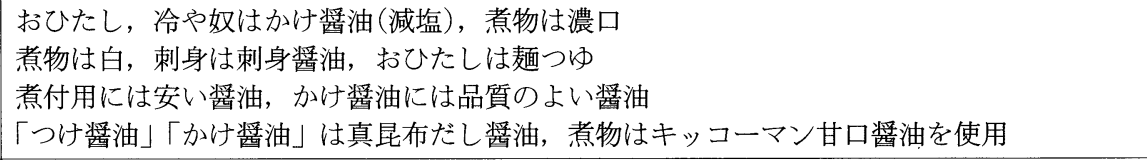 \\
\hline $\begin{array}{l}\text { 東 } \\
\text { 北 }\end{array}$ & $\begin{array}{l}\text { 秋田県 } \\
\text { 秋田県 } \\
\text { 秋田県 } \\
\text { 山形県 } \\
\text { 山形県 }\end{array}$ & 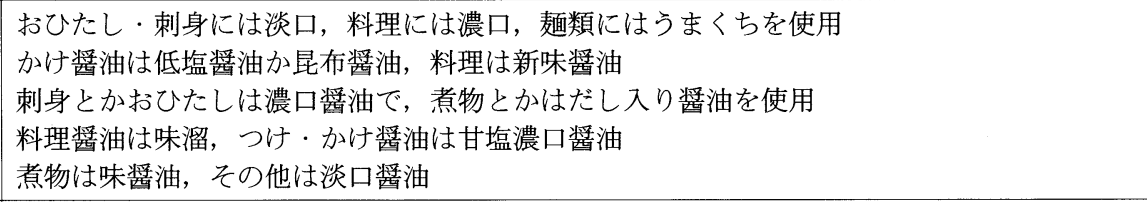 \\
\hline $\begin{array}{l}\text { 関 } \\
\text { 東 } \\
\text { 信 }\end{array}$ & $\begin{array}{l}\text { 栃木県 } \\
\text { 群馬県 } \\
\text { 群馬県 } \\
\text { 群馬県 } \\
\text { 群馬県 } \\
\text { 埼玉県 } \\
\text { 山梨県 } \\
\text { 山梨県 }\end{array}$ & 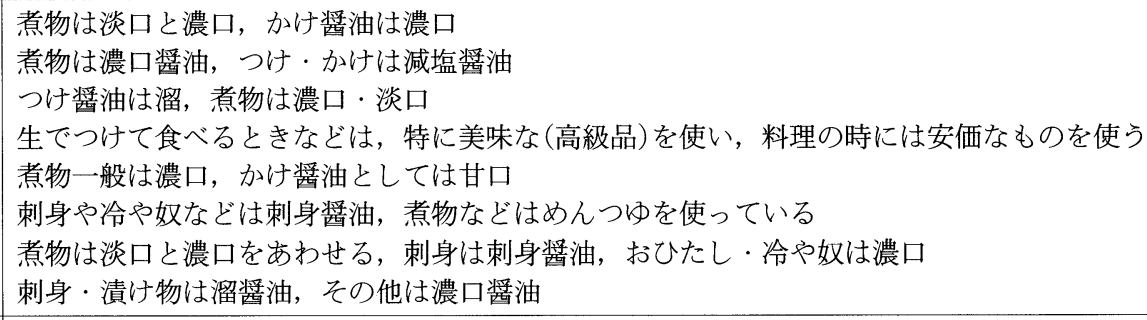 \\
\hline $\begin{array}{l}\text { 北 } \\
\text { 陸 }\end{array}$ & $\begin{array}{l}\text { 石川県 } \\
\text { 福井県 } \\
\text { 福井県 }\end{array}$ & 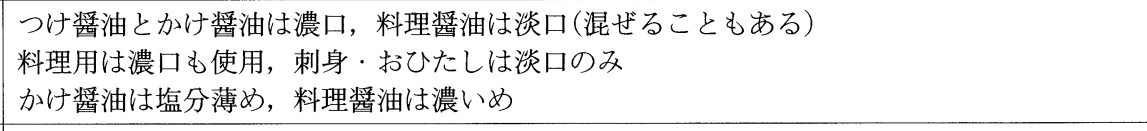 \\
\hline $\begin{array}{l}\text { 東 } \\
\text { 海 }\end{array}$ & $\begin{array}{l}\text { 静岡県 } \\
\text { 静岡県 } \\
\text { 愛知県 } \\
\text { 愛知県 } \\
\text { 愛知県 }\end{array}$ & 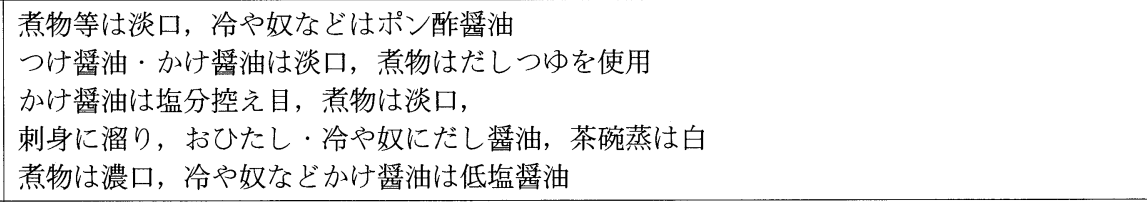 \\
\hline $\begin{array}{l}\text { 関 } \\
\text { 西 }\end{array}$ & $\begin{array}{l}\text { 和歌山県 } \\
\text { 和歌山県 } \\
\text { 和歌山県 } \\
\text { 和歌山県 } \\
\text { 大阪府 } \\
\text { 大阪府 }\end{array}$ & $\begin{array}{l}\text { 煮物には濃口, 刺身には溜, 冷や奴にはかつお奨油 } \\
\text { 煮物用は濃口・淡口・白を使い分け, 刺身は溜 } \\
\text { 煮物は淡口, 刺身や漬物は濃口 } \\
\text { 刺身は角長の溜, 煮物は淡口その他は丸大豆濃口 } \\
\text { 刺身は溜, 冷や奴はポン酢奨油, 煮物は濃口 } \\
\text { 煮物は濃口, 吸い物は淡口, 刺身・漬け物・冷や奴は溜 }\end{array}$ \\
\hline $\begin{array}{l}\text { 山 } \\
\text { 陰 }\end{array}$ & $\begin{array}{l}\text { 鳥取県 } \\
\text { 鳥取県 } \\
\text { 鳥取県 } \\
\text { 鳥取県 } \\
\text { 鳥取県 } \\
\text { 鳥取県 } \\
\text { 鳥取県 } \\
\text { 島根県 }\end{array}$ & 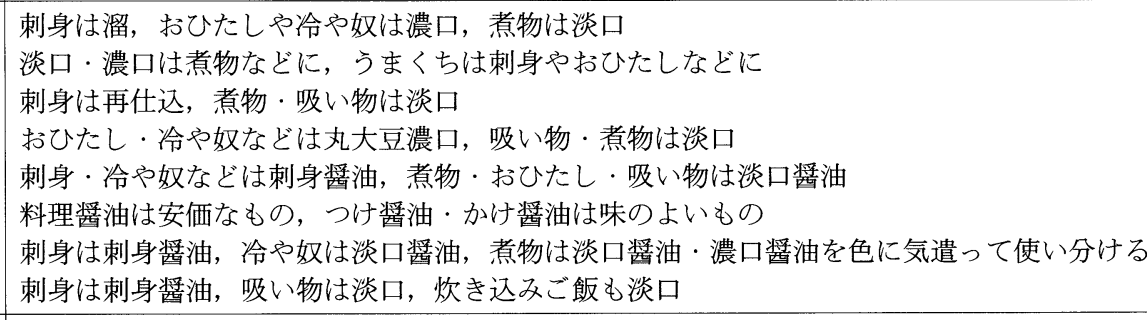 \\
\hline $\begin{array}{l}\text { 山 } \\
\text { 陽 }\end{array}$ & $\begin{array}{l}\text { 広島県 } \\
\text { 広島県 } \\
\text { 広島県 } \\
\text { 広島県 } \\
\text { 山口県 } \\
\text { 山口県 }\end{array}$ & 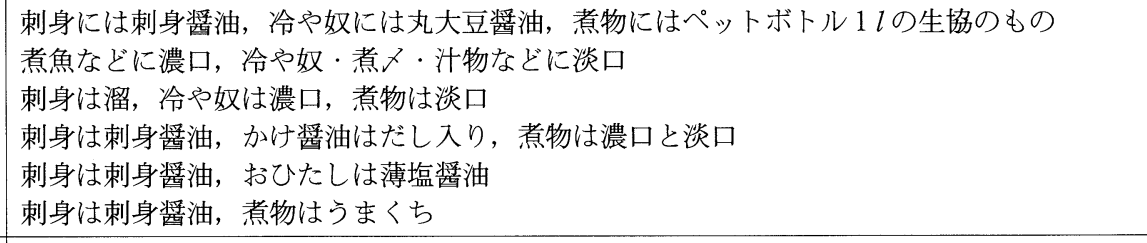 \\
\hline 国 & $\begin{array}{l}\text { 愛媛県 } \\
\text { 愛媛県 } \\
\text { 愛媛県 }\end{array}$ & $\begin{array}{l}\text { つけ滰油は少し甘味，かけ奨油は濃口，料理は淡口 } \\
\text { 刺身は刺身奨油，煮物は淡口，漬物などは濃口 } \\
\text { 刺身は溜，煮物は白だしと濃口の使い分け }\end{array}$ \\
\hline $\begin{array}{l}\text { 九 } \\
\text { 州 }\end{array}$ & $\begin{array}{l}\text { 熊本県 } \\
\text { 熊本県 } \\
\text { 熊本県 } \\
\text { 熊本県 } \\
\text { 熊本県 } \\
\text { 鹿児島県 } \\
\text { 鹿児島県 }\end{array}$ & 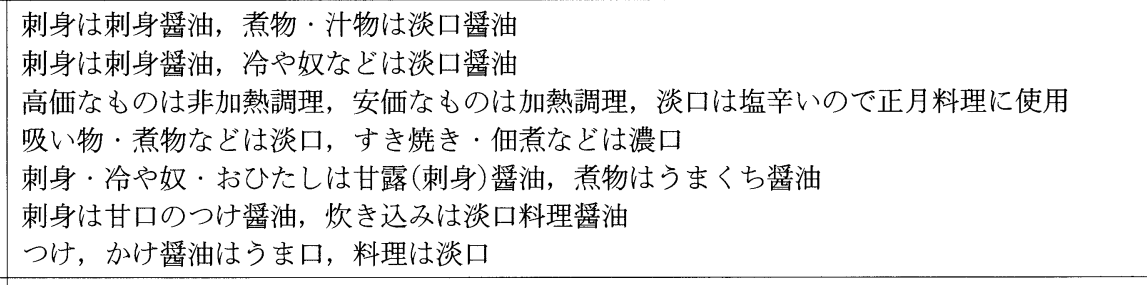 \\
\hline $\begin{array}{l}\text { 沖 } \\
\text { 縄 }\end{array}$ & $\begin{array}{l}\text { 沖縄県 } \\
\text { 沖縄県 } \\
\text { 沖縄県 }\end{array}$ & $\begin{array}{l}\text { 刺身は刺身奨油，おひたしなどはゆず奨油，煮物などは濃口 } \\
\text { 刺身はうまくち，煮物は淡口・うまくち } \\
\text { おひたし·冷や奴·刺身などには淡口，煮物など煮付けは濃口 }\end{array}$ \\
\hline
\end{tabular}




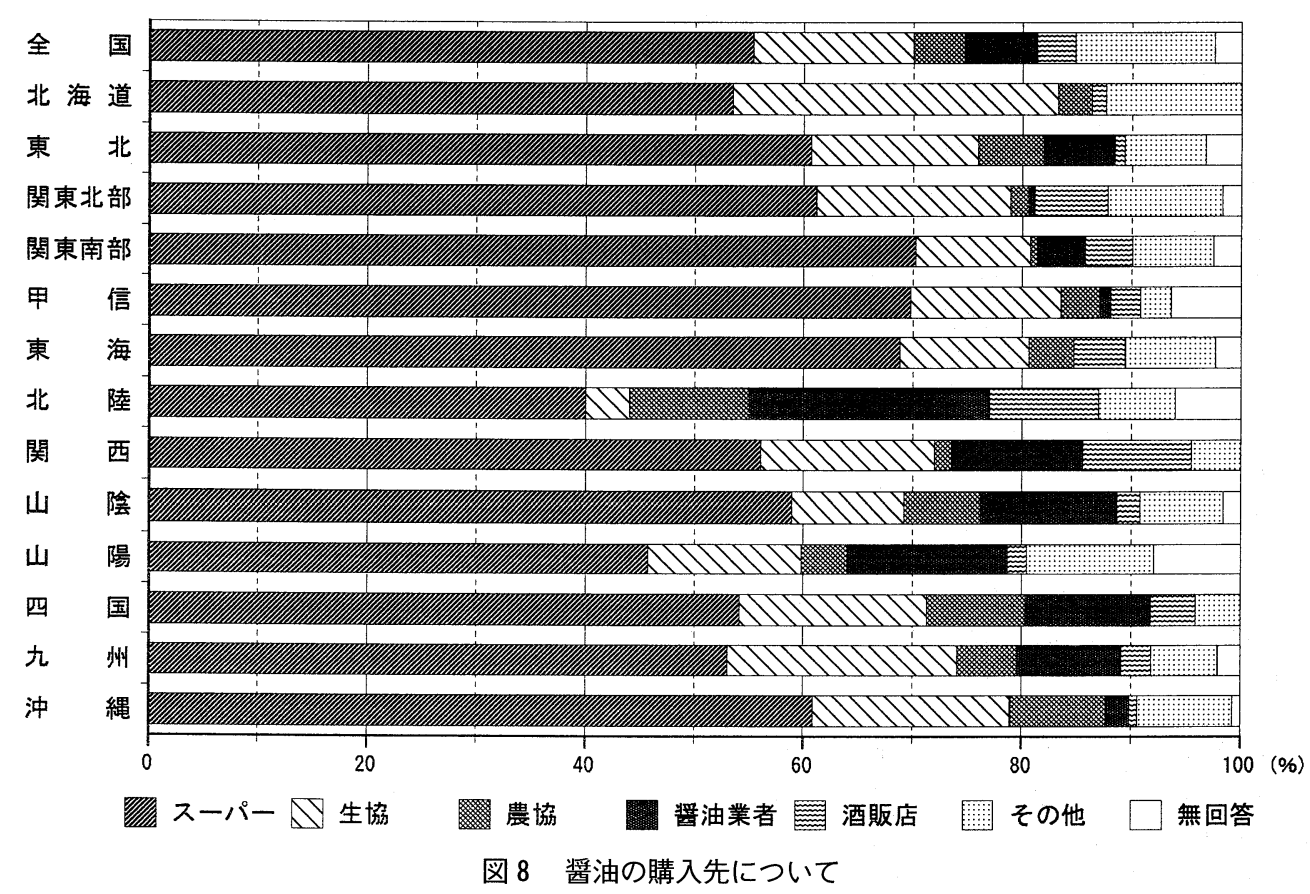

かつては, 調味料類の主な購入先だったと思われる酒 販店は,その割合を低下させている。最も多かった北陸 · 関西で $10 \%$, 関東北部では $7 \%$ であり，その他の地域で は $5 \%$ 以下となっている。また，その他には，わずかで はあるが通信販売で購入しているケースや贈答品で間に 合っているなどの回答があった。

\section{$N$ 要 約}

本研究では, アンケート調査の結果により奨油の好み の傾向と消費動向の解明を試みた。これまでの分析によ って得られた知見は以下の通りである。

主に用いられている酱油の種類は「濃口」であり, 東 日本でより多く, 西日本では若干少ない。「淡口」は西 日本が主体だが，北海道・東北でも比較的高い割合で用 いられている。また, 北海道·東北，山陽·九州·沖縄 では「昆布酱油」や「新味奨油」など，昆布だしやうま み成分を添加したその他の奨油が多く用いられているこ とがわかった。

消費者の奨油への「こだわり」は, 関東地方周辺で 「持っていない」割合が高く，その他の地域では「持っ ている」割合が高かった。「こだわり」を持っている消 費者の関心は，銘柄，原料 (丸大豆・有機栽培原料)， 塩分などであり，価格のみならず，使い慣れた銘柄や安 全な原料などへの関心の高さがみられた。また奨油の使 用法については，関西から九州にかけての西日本では， 料理に応じて奨油の使い分けをする割合が高く, 北海道 や東北でも約半数が使い分けていた。一方で関東・東 海・北陸では酱油の使い分けをしない割合が高く，濃口 酱油のみを使う例が多くみられた。

使い分けの差異が生じる要因については, 歴史や伝統 などの影響が強いと考えられるが, 詳細については今後
検討していきたい。

奨油の購入先は, スーパーマーケットからが圧倒的に 多かった。ついで生協であった。特徵的だったのは，北 陸以西の地域で奨油醸造業者から直接購入する割合が高 かったことである。

\section{謝辞}

アンケートにご協力いたたいた関係者の方々に感謝す る。また, 立正大学1999年度地理学基礎演習のメンバー とご指導いただいた同大学地理学教室大塚昌利教授に謝 意を表したい。また，一部の図の作成には谷謙二氏作成 のMANDARAを使用した。あわせて感謝したい。な お本論文は, 人文地理学会 (2000年11月 ·立命館大学), 経済地理学会関東支部例会（2002年 3 月 · 駒沢大学）で 発表した内容を再構成したものである。

\section{参考文献}

1）高木 亨：日本における奨油醸造業の立地形態，日本地 理学会発表要旨集，55，398-399（1999）

2）高木 亨：明治期以降における酱油醸造業年表, 地域研 究，40-2，19-26(2000a)

3）高木 亨：滰油における銘柄の地域性，2000年度人文地 理学会大会研究発表要旨, 108-109 (2000 b )

4) 高木 亨: 石川県の酱油醇造業集積地域, 井出策夫編著 : 産業集積の研究, 大明堂, 150-163 (2001 a)

5）高木 亨：金沢市大野町における奨油工場の協業化にと もなう奨油産地の変容, 日本地理学会発表要旨集, 62,86 (2001 b )

6）高木 亨：明治期以降に抢ける奨油醸造業の展開過程, 地域研究, 43-2, 1-22（2003）

7）（株）日刊経済通信社：酒類食品産業の生産 ·販売シェ ア一需給の動向と価格変動一, 1231p（2003）

8）石川寬子編著 : 地域と食文化, (財) 放送大学教育振興会, 181p (1999) 
9）石川寛子: 日本の食文化研究と地域性, 日本食生活学会 誌, 11- 3，200２08（2000）

10）キッコーマンの工場は, 千葉県野田市の他, 北海道千歳 市, 兵庫県高砂市に立地している. キッコーマン（株）: キ ッコーマン株式会社八十年史, 非売品, 719p（2000）

11）前揭10）

12）日本酱油協会資料による.

13）茂木孝也・松若昭夫：酱油について（その1）一江戸時
代の奨油の発達一, 伝統食品の研究, 12，22～31（1993）

14） 1984年に「めん類等用つゆ」としてJASに制定されてい ることからもわかるように，このころから普及が進んだと いえる. 前揭 2 ).

15）田村平治・平野正章共編：槒油の本, 柴田書店, $286 p$ (1971)

16）加藤純一：反比例する消費量と多様なしょうゆ利用，フ アインライブ, 19, 34〜35（1991） 